Scientia Agricola

http://dx.doi.org/10.1590/0103-9016-2014-0210

\title{
Purified cellulose, soybean hulls and citrus pulp as a source of fiber for weaned piglets
}

Leonardo Augusto Fonseca Pascoal ${ }^{*}$, Maria Cristina Thomaz ${ }^{2}$, Pedro Henrique Watanabe ${ }^{3}$, Urbano dos Santos Ruiz ${ }^{2}$, Alessandro Borges Amorim4, Everton Daniel², Susana Zaneti da Silva²

${ }^{1}$ Federal University of Paraiba - Dept. of Animal Science, Campus III, s/n, Centro - 58220-000 - Bananeiras, PB Brazil.

${ }^{2}$ São Paulo State University/FCAV - Dept. of Animal Science, Via de Acesso Prof. Paulo Donato Castellane s/n - 14884900 - Jaboticabal, SP - Brazil.

${ }^{3}$ Federal University of Ceará - Dept. of Animal Science, Av. Mister Hull, 2977 - Campus do Pici - 60021-970 Fortaleza, CE - Brazil.

${ }^{4}$ Federal University of Mato Grosso - Dept. of Animal Science, Rod. MT 270, km 6 - 18618-970 - Rondonópolis, MT - Brazil.

*Corresponding author <leonardo@cchsa.ufpb.br>

Edited by: Gerson Barreto Mourão

Received June 16, 2014

Accepted March 03, 2015
ABSTRACT: Dietary fiber is an important component, which has a direct effect on intake, digestion, and absorption of nutrients; and also alters intestinal microbiota and morphology according to solubility. One digestibility trial and one performance experiment were performed to evaluate the effects of sources of fiber in diets for 21 day weaned piglets. The experimental diets used in both trials consisted of a control diet and diets with purified cellulose, soybean hulls or citrus pulp as a main source of dietary fiber. To evaluate the digestibility of nutrients (Assay 1), the total feces and urine collection method was used. The fiber sources did not affect nutrient digestibility, except for soluble fiber, which increased with the inclusion of citrus (Citrus sinensis L.) pulp. To evaluate performance, morphophysiology and microbiology of the digestive tract of weaned piglets, a total of 32 castrated male piglets was used. Slaughter of animals was implemented at 35 and 50 days of age. The use of soybean (Glycine max L.) hulls and citrus pulp in diets increased the number of goblet cells and the density of villi in the jejunum. The viscosities of stomach and cecum contents increased due to the addition of citrus pulp. Soybean hulls and the citrus pulp included in diets reduced the occurrence of $E$. coli in the small intestines of piglets slaughtered at 35 days of age. Among the fiber sources, purified cellulose in piglet diets promotes better performance of animals, due to the modulation of the small intestine microbiota, with lower $\mathrm{E}$. coli occurrence resulting in higher villus density.

Keywords: dietary fiber, intestinal health, short-chain fatty acids, weaning, villus

\section{Introduction}

The prohibition of antibiotics as growth promoters in diets of weaned piglets has given rise to the need to search for alternatives. There are several technologies that can be evaluated and applied, and among these, the use of physiologically active dietary ingredients stands out. Fibrous ingredients in diets after weaning were evaluated in a way so as to make the modulation of intestinal microbiota possible, since the fibrous fraction is not digested enzymatically, and becomes available to microbial fermentation in the large intestine (Molist et al., 2009).

Dietary fiber is an important component in the diet of animals. This fraction of the feed directly affects intake, digestion, and the absorption of nutrients (Wenk, 2001), and can alter intestinal microbiota and morphology according to its solubility (Montagne et al., 2003). Dietary fiber can be divided into two types: (i) one rapidly fermentable (soluble fiber), and (ii) one partially or non-fermentable (insoluble fiber). Depending on the predominant fraction in the feed, these fibers can have diverse effects (Knudsen, 2001). Fiber can be beneficial due to certain physiological effects, such as increases in the rates of gastric and intestinal secretions, from the turnover of enterocytes and the stimulus to intestinal motility (Whitney et al., 2006).

The inclusion of a source of insoluble fiber in diets of piglets improved their intestinal morphology, increasing the length of villi when compared to animals fed diets containing sources of soluble fiber such as pectin
(Hedemann et al., 2006). Pigs fed diets rich in insoluble fiber had better protection against pathogenic bacteria than those fed with diets rich in soluble fiber (McDonald et al., 2001; Hopwood et al., 2002). On the other hand, soluble dietary fiber can serve as substrate for microbial fermentation in the intestine, producing short-chain fatty acids that may be harmful to pathogenic microorganisms (Drochner et al., 2004).

Since the ingredients have a varied composition in relation to insoluble and soluble fractions of dietary fiber, it is pertinent to evaluate the nutritional characteristics of the diets containing fibrous sources, such as purified cellulose, soybean (Glycine max L.) hulls, and citrus (Citrus sinensis L.) pulp, and their effects on the morphophysiological and microbiological characteristics of the digestive tract before including them in post-weaning diets, so as not to bring impairment to the performance of the weaned piglets.

\section{Material and Methods}

Experiments were carried out in Jaboticabal, in

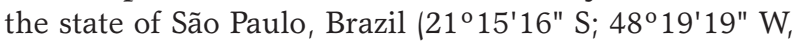
altitude $607 \mathrm{~m}$ ). The experimental protocols used in this study were approved by the Committee of Ethics for the Use of Animals (CEUA) of the Faculty of Agriculture and Veterinary Sciences, UNESP, Jaboticabal.

\section{Assay 1}

A total of 16 castrated male piglets of a commercial line were used in this trial, with an initial weight of 
$12.98 \pm 0.07 \mathrm{~kg}$. Animals were housed in cages for metabolic studies. A randomized block design was used to control differences in initial weight, with four treatments and four replicates, and one animal per experimental unit.

The experimental diets were: CD - Control diet - composed mainly of corn, soybean meal and a source of lactose; CEL - corn, soybean meal a source of lactose and $1.5 \%$ of purified cellulose; $\mathrm{SH}$ - corn, soybean meal a source of lactose and $3 \%$ of soybean hulls, and CP corn, soybean meal a source of lactose, and $9 \%$ of citrus pulp. Diets with inclusion of fiber sources contain the same quantities of crude fiber.

For the formulation of the experimental diets, the chemical composition of corn, soybean meal, purified cellulose, soybean hulls, and citrus pulp was analyzed and described in Table 1. The experimental diets were formulated to reach the minimal nutritional requirements of the animals from 32 to 50 days of age, according to Rostagno et al. (2005). No antibiotics nor growth promoters were added to the feed. The centesimal, chemical, and energy compositions of the experimental diets are shown in Table 2.

The trial lasted 12 days considered the first seven days for adaptation to cages and determined feed intake, which was defined according to intake for this stage based on the metabolic weight $\left(\mathrm{kg}^{0.75}\right)$ of each experimental unit. After the adaptation period, collection of samples was started and lasted five days.

Feeding was implemented twice a day, at $8 \mathrm{~h} 00$ and 17h00. The feed was weighed and wetted with water, in a proportion of $1: 1$, to avoid waste, reduce crumbling, and ease intake. After each meal, water was provided ad libitum. The method of total feces collection was used. The feces were collected twice a day, weighed, and then maintained frozen. Urine was collected once a day in

Table 1 - Chemical and energy compositions of the ingredients used to formulate experimental diets (values based on natural matter).

\begin{tabular}{|c|c|c|c|c|c|}
\hline $\begin{array}{l}\text { Nutrients and } \\
\text { energy }\end{array}$ & Corn & $\begin{array}{l}\text { Soybean } \\
\text { meal }\end{array}$ & $\begin{array}{l}\text { Purified } \\
\text { cellulose }\end{array}$ & $\begin{array}{l}\text { Soybean } \\
\text { hulls }\end{array}$ & $\begin{array}{l}\text { Citrus } \\
\text { pulp }\end{array}$ \\
\hline $\mathrm{DM}, \%$ & 88.7 & 90.3 & 96.5 & 90.3 & 88.9 \\
\hline OM, \% & 87.6 & 84.6 & 96.2 & 87.3 & 84.2 \\
\hline $\mathrm{CP}, \%$ & 9.2 & 47.9 & 0.3 & 11.1 & 8.2 \\
\hline $\mathrm{EE}, \%$ & 4.6 & 1.8 & - & 1.5 & 2.1 \\
\hline Starch, \% & 64.1 & 10.5 & - & 5.6 & 4.1 \\
\hline$C F, \%$ & 2.3 & 6.7 & 88.5 & 43.7 & 15.5 \\
\hline NDF, \% & 10.6 & 14.1 & 95.3 & 66.0 & 21.3 \\
\hline ADF, $\%$ & 3.9 & 9.6 & 93.5 & 51.1 & 11.1 \\
\hline Hemicellulose, \% & 6.7 & 4.5 & 1.8 & 14.9 & 10.2 \\
\hline TDF, $\%$ & 17.2 & 38.4 & 93.7 & 76.4 & 42.4 \\
\hline $\mathrm{IF}, \%$ & 16.0 & 35.4 & 93.1 & 70.7 & 11.7 \\
\hline $\mathrm{SF}, \%$ & 1.2 & 2.9 & 0.6 & 5.7 & 30.6 \\
\hline ME, kcal kg ${ }^{-1}$ & $3340^{1}$ & $3253^{1}$ & $487^{2}$ & $1882^{2}$ & $2578^{2}$ \\
\hline \multicolumn{6}{|c|}{$\begin{array}{l}\mathrm{DM}=\text { dry matter; } \mathrm{OM}=\text { organic matter; } \mathrm{CP}=\text { crude protein; } \mathrm{EE}=\text { ether } \\
\text { extract; } \mathrm{CF}=\text { crude fiber; NDF = neutral detergent fiber; } \mathrm{ADF}=\text { acid detergent } \\
\text { fiber; TDF = total dietetic fiber; IF = insoluble fiber; } \mathrm{SF}=\text { soluble fiber; } \mathrm{ME}= \\
\text { metabolizable energy; }{ }^{1} \text { Metabolizable energy value described by Rostagno et } \\
\text { al. (2005); }{ }^{2} \text { Data obtained in previous study. }\end{array}$} \\
\hline
\end{tabular}

plastic buckets containing $20 \mathrm{~mL}$ of $\mathrm{HCl}$ in the ratio of $1: 1$ distilled water to acid, with the objective of not allowing any loss of nitrogen and the proliferation of bacteria. The volume of urine produced was measured and an aliquot of $20 \%$ was removed and maintained frozen. Ferric oxide $\left(\mathrm{Fe}_{2} \mathrm{O}_{3}\right)$ was used as a fecal marker to determine the beginning and the end of the collection period. At the end of the experiment, the feces of each animal were homogenized, and a representative sample

Table 2 - Centesimal, chemical, and energy compositions of the experimental $\operatorname{diets}^{1}$ (Assay 1).

\begin{tabular}{|c|c|c|c|c|}
\hline \multirow{2}{*}{ Feedstuffs } & \multicolumn{4}{|c|}{ Treatments } \\
\hline & $C D$ & CEL & $\mathrm{SH}$ & $\mathrm{CP}$ \\
\hline Corn & 50.74 & 48.08 & 47.21 & 41.86 \\
\hline Soybean meal & 33.86 & 34.34 & 33.82 & 33.66 \\
\hline Milk Product² & 10.00 & 10.00 & 10.00 & 10.00 \\
\hline Soybean oil & 1.97 & 2.66 & 2.55 & 2.27 \\
\hline Citrus pulp & - & - & - & 9.00 \\
\hline Soybean hulls & - & - & 3.00 & - \\
\hline Purified cellulose & - & 1.50 & - & - \\
\hline Dicalcium phosphate & 2.05 & 2.05 & 2.05 & 2.06 \\
\hline Limestone & 0.43 & 0.43 & 0.43 & 0.19 \\
\hline L-Lysine.HCl, 79 \% & 0.27 & 0.26 & 0.26 & 0.27 \\
\hline DL-Methionine, 99 \% & 0.08 & 0.08 & 0.08 & 0.09 \\
\hline L-Threonine, 98 \% & 0.11 & 0.11 & 0.11 & 0.11 \\
\hline L-Tryptophan, 99 \% & - & - & - & - \\
\hline Salt & 0.37 & 0.37 & 0.37 & 0.37 \\
\hline Antioxidant & 0.02 & 0.02 & 0.02 & 0.02 \\
\hline Min. and vit. supl. ${ }^{3}$ & 0.10 & 0.10 & 0.10 & 0.10 \\
\hline Kaolin & - & - & - & - \\
\hline Total & 100.00 & 100.00 & 100.00 & 100.00 \\
\hline \multicolumn{5}{|l|}{ Analyzed values } \\
\hline Metabolizable energy, kcal kg-1 & 3325 & 3325 & 3325 & 3325 \\
\hline Crude protein, $\%$ & 22.38 & 22.36 & 22.36 & 22.21 \\
\hline Calcium, \% & 0.83 & 0.83 & 0.84 & 0.88 \\
\hline Available phosphorus, $\%$ & 0.45 & 0.45 & 0.45 & 0.45 \\
\hline Lactose, $\%$ & 7.00 & 7.00 & 7.00 & 7.00 \\
\hline Starch, \% & 36.07 & 34.42 & 33.97 & 30.73 \\
\hline Crude fiber, $\%$ & 3.45 & 4.75 & 4.68 & 4.63 \\
\hline Neutral detergent fiber, $\%$ & 10.16 & 11.38 & 11.76 & 11.11 \\
\hline Acid detergent fiber, $\%$ & 5.25 & 6.60 & 6.64 & 5.88 \\
\hline Hemicellulose, $\%$ & 4.90 & 4.78 & 5.11 & 5.22 \\
\hline Total dietetic fiber, \% & 21.73 & 22.86 & 23.40 & 23.94 \\
\hline Insoluble fiber, \% & 20.13 & 21.27 & 21.67 & 19.69 \\
\hline Soluble fiber, $\%$ & 1.60 & 1.59 & 1.73 & 4.26 \\
\hline Digestible lisine ${ }^{4}, \%$ & 1.34 & 1.33 & 1.34 & 1.33 \\
\hline Digestible methionine ${ }^{4}, \%$ & 0.37 & 0.37 & 0.37 & 0.38 \\
\hline Digestible threonine ${ }^{4}, \%$ & 0.84 & 0.85 & 0.84 & 0.84 \\
\hline Digestible tryptophan ${ }^{4}, \%$ & 0.24 & 0.24 & 0.24 & 0.23 \\
\hline
\end{tabular}

${ }^{1} \mathrm{CD}=$ control diet; $\mathrm{CEL}=$ diet containing $1.5 \%$ purified cellulose; $\mathrm{SH}=$ diet containing $3 \%$ soybean hulls and $\mathrm{CP}=$ diet containing $9 \%$ citrus pulp; ${ }^{2}$ Nuklospray K21-70 \% Lactose; ${ }^{3}$ Mineral and vitamin supplement - did not contain any type of growth promoter. Guaranteed levels per $\mathrm{kg}$ of feed: Vit. A - 4.000 U.I.; Vit. D3 - 220 U.I.; Vit. E - 22 mg; Vit. K - 0.5 mg; Vit B2 -

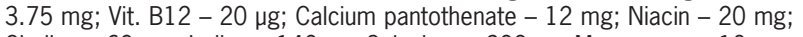
Choline - 60 mg; lodine - $140 \mu g$; Selenium - $300 \mu g$; Manganese - 10 mg; Zinc - 100 mg; Copper - 10 mg; Iron - 99 mg. ${ }^{4}$ Calculated values according to Rostagno et al. (2005). 
was taken to determine the first dry matter, which was then ground in a knife-type mill with $1 \mathrm{~mm}$ sieves for laboratory analyses.

The content of dry matter (DM), organic matter $(\mathrm{OM})$, crude protein (CP), mineral matter, neutral detergent fiber $(\mathrm{NDF})$, and acid detergent fiber $(\mathrm{ADF})$ were determined according to AOAC (2005). The gross energy (GE) of the ingredients, feed, feces, and urine was determined in an American Parr-type bomb calorimeter. Total starch was determined according to the Hendrix extraction methodology (1993), and dinitrosalicylic acid reagent (Miller, 1959) was used for the colorimetric reading. Total dietary fiber (TDF), insoluble fiber (IF), and soluble fiber (SF) were analyzed according to AOAC (2005). The coefficients of digestibility of the nutrients and energy, and the coefficient of metabolizability of the energy were calculated from the resulting values. The digestible nutrients, digestible energy, and metabolizable energy of the experimental diets were obtained using formulae described by Matterson et al. (1965).

\section{Assay 2}

To evaluate the productive performance, morphophysiology, and microbiology of the digestive tract of piglets, a total of 32 castrated piglets, weaned at 21 days, from the same commercial line were used, with an initial weight of $6.22 \pm 0.59 \mathrm{~kg}$. They were housed in pens of $2.55 \mathrm{~m}^{2}$ each, equipped with linked, leveled water troughs and semi-automatic feeders. During all the experimental period, wooden pens with $100 \mathrm{~W}$ incandescent light bulbs were used, affording individual heating to the piglets.

For the evaluation of performance (daily weight gain, daily feed intake, and feed conversion), a randomized block design was used to control differences in initial weight, with four treatments and eight replicates per treatment during the period of 21 to 35 days of age, and four replicates per treatment during the period of 35 to 50 days of age. In both periods, the experimental unit was represented by one piglet. For this trial, the experimental diets were the same as those used in Trial 1 , but only the phases from 21 to 35 and 36 to 50 days of age were considered according to Rostagno et al. (2005). No antibiotics nor growth promoters were added to the feed. The centesimal, chemical, and energy compositions of the experimental diets are shown in Table 3.

During the performance assay, two slaughters were performed, one at 35 days of age and the other at the end of the experimental period, at 50 days of age. To evaluate the morphophysiological and microbiological characteristics, a $4 \times 2$ factorial design was used (four diets and two slaughter ages), and the experimental unit was represented by one animal. Slaughter of the piglets was by electronarcosis followed by exsanguination. Afterwards, samples were collected to evaluate the following digestive system characteristics: $\mathrm{pH}$ and viscosity and short-chain fatty acid content in the intestines, structure and ultrastructure of the small intestine, and microbiological analyses.
Immediately after slaughter, the contents of the stomach, small intestine and cecum were put in plastic containers to determine $\mathrm{pH}$, which was determined with the aid of a digital $\mathrm{pH}$ meter. A sample of each segment was homogenized, diluted with distilled water in the proportion of $1: 1$, and centrifuged at $12,000 \times g$ for 8 min, and the supernatant was used to determine viscosity, by using a digital viscometer, at a rotation of $60 \mathrm{~s}^{-1}$.

To evaluate the concentration of short-chain fatty acids in the contents of the ileum-cecum portion, a sample of approximately $10 \mathrm{~g}$ was removed, weighed, and acidified with $30 \mathrm{~mL}$ of formic acid at $16 \%$ to inactivate the fermenting processes. The samples were maintained under refrigeration for $72 \mathrm{~h}$ while being homogenized twice a day. After this period, they were centrifuged at $5,200 \mathrm{xg}$ at $15{ }^{\circ} \mathrm{C}$ for $15 \mathrm{~min}$ and the supernatant was frozen for subsequent determination of the concentrations of short-chain fatty acids. This determination was performed by gas chromatography (Erwin et al., 1961). The gas chromatograph was equipped with glass columns three meters long $\times 1 / 4$ " diameter, packaged with 80/120 Carbopack B-DA/4 \% Carbowax 20M. The number of replicates per sample was that necessary until the difference between readings was below $5 \%$.

To evaluate the structure of the small intestine, samples $( \pm 3 \mathrm{~cm})$ were collected from the duodenum, middle portion of jejunum and cecum, which were opened in the region of the mesenteric border and placed in Bouin's fixative solution for $24 \mathrm{~h}$. After this period, the samples were washed in running water and $70 \%$ ethanol to remove the fixative, and then dehydrated in a crescent series of alcohols, from $70 \%$ to $100 \%$, cleaned in xylene, and set in paraffin. Microtomy of the samples was performed over a width of $5 \mu \mathrm{m}$, and 12 to $14 \mathrm{semi}$ serial cuts were made for each segment of each animal. Staining of sections was performed with hematoxylineosin, and goblet cell count was performed using the periodic acid Schiff-PAS technique (Tolosa et al., 2003).

A light microscope, coupled to a system for capturing images, and an image analyzing system program, magnified 125 times, were used to read the histological slides when evaluating villus height (VH), and crypt depth (CD). Thirty readings were taken per sample for each parameter. With the results of $\mathrm{VH}$ and $\mathrm{CD}$, the VH/CD ratio was calculated. To evaluate the number of goblet cells (GC), 15 counts were performed per sample, one count per villus, and the result obtained was expressed in number of goblet cells per villus.

For the analyses of the ultrastructure of the small intestine, samples $( \pm 1 \mathrm{~cm})$ of the duodenum and middle portion of the jejunum were also collected immediately after slaughter. They were washed in a phosphate buffer solution (0.1 M and $\mathrm{pH} 7.4)$ and fixed in glutaraldehyde. Then, they were dehydrated in a crescent series of ethyl alcohol, dried in a critical point dryer using $\mathrm{CO}_{2}$, mounted with gold metallic palladium, and observed in an electron-micrograph made by an elec- 
Table 3 - Centesimal, chemical, and energy compositions of the experimental diets ${ }^{1}$.

\begin{tabular}{|c|c|c|c|c|c|c|c|c|}
\hline \multirow{3}{*}{ Ingredients } & \multicolumn{8}{|c|}{ Experimental Diets } \\
\hline & \multicolumn{4}{|c|}{21 to 35 days of age } & \multicolumn{4}{|c|}{36 to 50 days of age } \\
\hline & $C D$ & CEL & SH & $\mathrm{CP}$ & $C D$ & CEL & $\mathrm{SH}$ & $\mathrm{CP}$ \\
\hline Corn & 47.13 & 45.09 & 44.19 & 38.73 & 50.74 & 48.08 & 47.21 & 41.86 \\
\hline Soybean meal & 29.63 & 29.98 & 29.49 & 29.32 & 33.86 & 34.34 & 33.82 & 33.66 \\
\hline Milk Product² & 17.14 & 17.14 & 17.14 & 17.14 & 10.00 & 10.00 & 10.00 & 10.00 \\
\hline Soybean oil & 1.48 & 1.96 & 1.86 & 1.62 & 1.97 & 2.66 & 2.55 & 2.27 \\
\hline Citrus pulp & - & - & - & 9.00 & - & - & - & 9.00 \\
\hline Soybean hulls & - & - & 3.00 & - & - & - & 3.00 & - \\
\hline Purified cellulose & - & 1.50 & - & - & - & 1.50 & - & - \\
\hline Dicalcium phosphate & 2.69 & 2.69 & 2.69 & 2.69 & 2.05 & 2.05 & 2.05 & 2.06 \\
\hline Limestone & 0.15 & 0.15 & 0.15 & 0.00 & 0.43 & 0.43 & 0.43 & 0.19 \\
\hline L-Lysine.HCl, 79 \% & 0.53 & 0.53 & 0.52 & 0.54 & 0.27 & 0.26 & 0.26 & 0.27 \\
\hline DL-Methionine, 99 \% & 0.16 & 0.16 & 0.16 & 0.16 & 0.08 & 0.08 & 0.08 & 0.09 \\
\hline L-Threonine, $98 \%$ & 0.27 & 0.27 & 0.27 & 0.27 & 0.11 & 0.11 & 0.11 & 0.11 \\
\hline L-Tryptophan, 99 \% & 0.04 & 0.04 & 0.04 & 0.05 & - & - & - & - \\
\hline Salt & 0.37 & 0.37 & 0.37 & 0.36 & 0.37 & 0.37 & 0.37 & 0.37 \\
\hline Antioxidant & 0.02 & 0.02 & 0.02 & 0.02 & 0.02 & 0.02 & 0.02 & 0.02 \\
\hline Min. and vit. supl. ${ }^{3}$ & 0.10 & 0.10 & 0.10 & 0.10 & 0.10 & 0.10 & 0.10 & 0.10 \\
\hline Kaolin & 0.29 & - & - & - & - & - & - & - \\
\hline Total & 100.00 & 100.00 & 100.00 & 100.00 & 100.00 & 100.00 & 100.00 & 100.00 \\
\hline \multicolumn{9}{|l|}{ Analyzed values } \\
\hline Metabolizable energy, $\mathrm{kcal}^{\mathrm{kg}}{ }^{-1}$ & 3325 & 3325 & 3325 & 3325 & 3325 & 3325 & 3325 & 3325 \\
\hline Crude protein, $\%$ & 21.24 & 21.23 & 21.23 & 21.08 & 22.38 & 22.36 & 22.36 & 22.21 \\
\hline Calcium, \% & 0.89 & 0.89 & 0.90 & 0.97 & 0.83 & 0.83 & 0.84 & 0.88 \\
\hline Available phosphorus, $\%$ & 0.56 & 0.56 & 0.56 & 0.56 & 0.45 & 0.45 & 0.45 & 0.45 \\
\hline Lactose, $\%$ & 12.00 & 12.00 & 12.00 & 12.00 & 7.00 & 7.00 & 7.00 & 7.00 \\
\hline Starch, \% & 33.32 & 32.04 & 31.58 & 28.27 & 36.07 & 34.42 & 33.97 & 30.73 \\
\hline Crude fiber, $\%$ & 3.09 & 4.40 & 4.33 & 4.27 & 3.45 & 4.75 & 4.68 & 4.63 \\
\hline Neutral detergent fiber, \% & 9.18 & 10.44 & 10.83 & 10.17 & 10.16 & 11.38 & 11.76 & 11.11 \\
\hline Acid detergent fiber, $\%$ & 4.70 & 6.06 & 6.11 & 5.34 & 5.25 & 6.60 & 6.64 & 5.88 \\
\hline Hemicellulose, $\%$ & 4.47 & 4.38 & 4.72 & 4.82 & 4.90 & 4.78 & 5.11 & 5.22 \\
\hline Total dietetic fiber, \% & 19.48 & 20.67 & 21.21 & 21.73 & 21.73 & 22.86 & 23.40 & 23.94 \\
\hline Insoluble fiber, \% & 18.05 & 19.24 & 19.65 & 17.65 & 20.13 & 21.27 & 21.67 & 19.69 \\
\hline Soluble fiber, $\%$ & 1.43 & 1.43 & 1.57 & 4.08 & 1.60 & 1.59 & 1.73 & 4.26 \\
\hline Digestible lisine ${ }^{4}, \%$ & 1.53 & 1.53 & 1.52 & 1.53 & 1.34 & 1.33 & 1.34 & 1.33 \\
\hline Digestible methionine ${ }^{4}, \%$ & 0.44 & 0.43 & 0.43 & 0.43 & 0.37 & 0.37 & 0.37 & 0.38 \\
\hline Digestible threonine ${ }^{4}, \%$ & 0.96 & 0.96 & 0.96 & 0.96 & 0.84 & 0.85 & 0.84 & 0.84 \\
\hline Digestible tryptophan ${ }^{4}, \%$ & 0.26 & 0.26 & 0.26 & 0.27 & 0.24 & 0.24 & 0.24 & 0.23 \\
\hline
\end{tabular}

${ }^{1} \mathrm{CD}=$ control diet; $\mathrm{CEL}=$ diet containing $1.5 \%$ purified cellulose; $\mathrm{SH}=$ diet containing $3 \%$ soybean hulls and $\mathrm{CP}=$ diet containing $9 \%$ citrus pulp; ${ }^{2}$ Nuklospray K21-70 \% Lactose; ${ }^{3}$ Mineral and vitamin supplement - did not contain any type of growth promoter. Guaranteed levels per kg of feed: Vit. A - 4.000 U.I.; Vit. D3 -

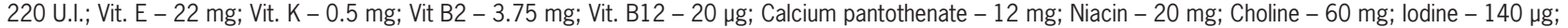
Selenium - 300 нg; Manganese - 10 mg; Zinc - 100 mg; Copper - 10 mg; Iron - 99 mg. ${ }^{4}$ Calculated values according to Rostagno et al. (2005).

tron microscope scan, operated on $15 \mathrm{kV}$. Electron micrographs of five areas per sample were taken for the purpose of estimating the density of the villi (number of villi per $\mathrm{cm}^{2}$ ).

In order to perform microbiological analyses, samples were collected from the contents of the small intestine and the cecum, and were packed and stored at $5{ }^{\circ} \mathrm{C}$. Immediately after finishing the collections, the samples were taken to the laboratory for microbiological quantification for Lactobacilus spp. and Escherichia coli. Appropriate plating techniques were adopted for each bacterium, according to those described by Lennette et al. (1985) and Krieg and Holt (1994).
All data were submitted to variance analysis (SAS Institute, Cary, NC Version 9.0). The normality of the errors was tested using the Cramer-von Misses test. Digestibility and performance data were compared by the Tukey test $(5 \%)$. For the morphophysiological and microbiological characteristics, a 4 $\times 2$ factorial arrangement was used (four diets and two slaughter ages) and means were compared by the Tukey test (5\%). Data referring to microbiology, originally in $\mathrm{cfu} \mathrm{g}^{-1}$ (colony-forming units per $\mathrm{g}$ of sample), were transformed by the function $y=\log x$, where $x$ is the number of colony-forming units per $g$ of sample $\left(\mathrm{cfu} \mathrm{g}^{-1}\right)$. 


\section{Results and Discussion}

\section{Assay 1}

No differences were observed $(p>0.05)$ for coefficients of digestibility from the nutrients in relation to the inclusion of the sources of fiber, with the exception of soluble fiber, which increased $(p<0.01)$ with the inclusion of citrus pulp in the diet (Table 4). This ingredient is high in soluble fiber, and most of this fiber is pectin, which is highly fermentable in the digestive tract of pigs (Drochner et al., 2004). The same result was verified by Freire et al. (2000) and Schavion et al. (2004), who evaluated beet pulp in piglets, which is rich in soluble fiber, compared to other fibrous ingredients such as wheat bran, soybean hulls, and alfalfa meal. For the insoluble fiber and total

Table 4 - Coefficients of digestibility and metabolizability of experimental diets - Assay 1.

\begin{tabular}{|c|c|c|c|c|c|c|}
\hline \multirow{2}{*}{$\begin{array}{l}\text { Coefficients of } \\
\text { digestibility and } \\
\text { metabolizability, \% }\end{array}$} & \multicolumn{4}{|c|}{ Experimental diets ${ }^{1}$} & \multirow{2}{*}{$\mathrm{CV}^{2}(\%)$} & \multirow{2}{*}{$p$-value } \\
\hline & $C D$ & CEL & $\mathrm{SH}$ & $\mathrm{CP}$ & & \\
\hline DM & 89.1 & 87.6 & 87.15 & 88.0 & 2 & NS \\
\hline OM & 90.6 & 88.9 & 88.64 & 89.5 & 2 & NS \\
\hline MM & 63.9 & 64.9 & 63.4 & 63.3 & 7 & NS \\
\hline $\mathrm{CP}$ & 86.7 & 86.3 & 86.2 & 84.7 & 3 & NS \\
\hline Starch & 98.3 & 98.3 & 97.9 & 97.7 & 1 & NS \\
\hline CF & 63.2 & 48.2 & 54.2 & 64.2 & 18 & NS \\
\hline NDF & 68.3 & 60.1 & 63.5 & 69.1 & 13 & NS \\
\hline ADF & 64.7 & 56.7 & 58.1 & 74.4 & 16 & NS \\
\hline Hemicellulose & 72.3 & 64.6 & 70.8 & 62.5 & 13 & NS \\
\hline TDF & 75.9 & 73.9 & 74.8 & 78.3 & 6 & NS \\
\hline IF & 79.0 & 74.1 & 75.4 & 76.5 & 5 & NS \\
\hline SF & 77.7 b & $71.3 \mathrm{bc}$ & $67.4 \mathrm{c}$ & $87.1 \mathrm{a}$ & 6 & * \\
\hline GE & 89.1 & 88.1 & 87.3 & 88.2 & 2 & NS \\
\hline $\mathrm{CMGE}^{3}$ & 84.7 & 85.1 & 84.5 & 85.3 & 2 & NS \\
\hline
\end{tabular}

${ }^{1} \mathrm{CD}=$ control diet; $\mathrm{CEL}=$ diet containing $1.5 \%$ purified cellulose; $\mathrm{SH}=$ diet containing $3 \%$ soybean hulls and $\mathrm{CP}=\operatorname{diet}$ containing $9 \%$ citrus pulp; ${ }^{2}$ Coefficients of variation; Averages followed by the same letter in the row do not differ (Tukey, $p>0.05$ ); ${ }^{3}$ Coefficient of metabolizability of gross energy; $\mathrm{NS}=$ not significant; * $(p<0.05) ; \mathrm{DM}=$ dry matter; $\mathrm{OM}=$ organic matter; $\mathrm{MM}=$ mineral matter; $\mathrm{CP}=$ crude protein; $\mathrm{CF}=$ crude fiber; $\mathrm{NDF}=$ neutral detergent fiber; $\mathrm{ADF}=$ acid detergent fiber; $\mathrm{TDF}=$ total dietetic fiber; $\mathrm{IF}=$ insoluble fiber; $\mathrm{SF}=$ soluble fiber; $\mathrm{GE}=$ gross energy. dietary fiber, the absence of effects on digestibility may be due to a low increase in insoluble and total dietary fiber (Table 2) with the inclusion of fiber sources.

\section{Assay 2}

Piglets that received diets containing citrus pulp from 21 to 35 days of age had lower daily feed intake $(p$ $<0.01)$ and daily weight $(p<0.01)$ gain and worse feed conversion $(p<0.02)$ when compared to piglets fed on the other diets (Table 5). However, from 21 to 50 days of age, the addition of purified cellulose to the diets of piglets promoted greater daily weight gain $(p<0.01)$ and daily feed intake $(p<0.01)$ when compared to the other sources of fiber. For feed conversion, the piglets receiving the diet containing purified cellulose presented an improvement of $23 \%(p<0.05)$ when compared to the piglets receiving citrus pulp in the diets and $6 \%$ better compared to those fed the control diet.

This could be due to the type of fiber present in these two ingredients, which is more soluble and highly fermentable, and increases the production of short chain fatty acids in the large intestine, alters energy metabolism, reduces feed intake, and consequently worsens weight gain (Montagne et al., 2003; Pluske et al., 2003). In relation to diets containing citrus pulp, the reduction in daily feed intake, the worse weight gain and feed conversion can be justified by low palatability of the ingredient to swine, as stated by Watanabe et al. (2010) when using citrus pulp in the diets of finishing pigs.

Good performance was observed when adding purified cellulose in the diets of piglets, also verified by other authors (Han et al., 2005; Hanczakoswska et al., 2008) when evaluating levels of purified cellulose inclusion. Han et al., (2005) and Hanczakoswska et al., (2008) observed improvements in productive parameters and parameters related to the intestinal health of the animals. These differences in results are related to the type and quantity of fiber added to the diets (Mateos et al., 2006; Molist et al., 2009). Högberg and Lindberg (2004) suggest that positive effects in weight gain when the animals received sources of fiber in the diets can be related to the increase in size of the digestive organs.

Table 5 - Daily feed intake, daily weight gain and feed conversion of weaned piglets according to the inclusion of sources of fiber in diets.

\begin{tabular}{|c|c|c|c|c|c|c|}
\hline & \multicolumn{4}{|c|}{ Experimental diets $^{1}$} & \multirow{2}{*}{$\mathrm{CV}(\%)^{2}$} & \multirow{2}{*}{$p$-value } \\
\hline & $C D$ & CEL & $\mathrm{SH}$ & $\mathrm{CP}$ & & \\
\hline \multicolumn{7}{|c|}{21 to 35 days } \\
\hline DFI (g) & $339.03 \mathrm{a}$ & $344.65 a$ & $345.42 \mathrm{a}$ & $271.18 b$ & 15 & * \\
\hline DWG (g) & $192.45 \mathrm{a}$ & $217.65 \mathrm{a}$ & $217.91 \mathrm{a}$ & $98.49 \mathrm{~b}$ & 29 & * \\
\hline $\mathrm{FC}$ & $1.92 \mathrm{~b}$ & $1.70 \mathrm{~b}$ & $1.71 \mathrm{~b}$ & $2.78 \mathrm{a}$ & 19 & * \\
\hline \multicolumn{7}{|c|}{21 to 50 days } \\
\hline DFI (g) & $617.03 a b$ & $623.96 \mathrm{a}$ & $525.10 b$ & $419.48 \mathrm{c}$ & 8 & * \\
\hline DWG (g) & $402.40 a b$ & $435.94 \mathrm{a}$ & $321.35 b c$ & $223.75 c$ & 13 & * \\
\hline $\mathrm{FC}$ & $1.54 \mathrm{ab}$ & $1.45 \mathrm{~b}$ & $1.66 \mathrm{ab}$ & 1.89 a & 10 & * \\
\hline
\end{tabular}

${ }^{1} \mathrm{CD}=$ control diet; $\mathrm{CEL}=$ diet containing $1.5 \%$ purified cellulose; $\mathrm{SH}=$ diet containing $3 \%$ soybean hulls and $\mathrm{CP}=$ diet containing $9 \%$ citrus pulp; DFI = daily feed intake; DWG = daily weight gain; FC = feed conversion; ${ }^{2}$ Coefficient of variation. Averages followed by the same letter in the row do not differ (Tukey, $p>$ $0.05) ;{ }^{*}(p<0.05)$. 
The addition of sources of fiber to the diets of weaned piglets did not influence $(p>0.05)$ the values of $\mathrm{pH}$ in the contents of the segments of the digestive tract (Table 6). However, the $\mathrm{pH}$ in the cecum content was higher $(p<0.05)$ in animals slaughtered at 35 days in relation to those slaughtered at 50 days of age. The viscosity in the contents of the small intestine was not affected $(p>0.05)$ by the sources of fiber in the diets, but was different $(p<0.01)$ by slaughter age, confirming that the animals slaughtered at 50 days had lower values.

In relation to the viscosity in the contents of the stomach $(p<0.05)$ and cecum $(p<0.01)$, interaction was observed among the sources of fiber in the diets and slaughter age (Table 7). Slaughter age influenced the viscosities in the contents of the stomach and of the cecum, and greater values were observed for the animals slaughtered at 35 days of age, except for those that received the diet containing soybean hulls, for which there was no difference between slaughter ages.

The sources of fiber did not affect $(p>0.05)$ the viscosities in the content of the stomach at 35 days and of the cecum at 50 days of age. However, in the contents of the stomach at 50 days of age, lower viscosities were observed $(p<0.05)$ in the animals that received the control diet and the diet containing purified cellulose when compared to the animals that consumed citrus pulp in the diet. In the cecum, lowest $(p<0.01)$ viscosities at 35 days of age were found in piglets fed with control diets and with the inclusion of soybean hulls when compared to the piglets receiving diets containing purified cellulose and citrus pulp.
The quantities of Lactobacillus ssp. were not affected by the sources of fiber in the diets or by slaughter age. Similar results were observed by Molist et al. (2009) when evaluating three diets containing wheat bran and/or beet pulp, and they found no changes in the occurrence of Lactobacillus ssp. Conversely, Bikker et al. (2006) observed a higher occurrence of Lactobacillus ssp. in the intestine of weaned piglets fed diets containing high quantities of soluble carbohydrates.

The solubility of the fiber affected $\mathrm{pH}$ and viscosity of the digestive tract contents, aside from the effects over the capacity of water retention and transit time of the digesta (Carneiro et al., 2008; Wenk, 2001). Thus, the more soluble this feed fraction, the greater the viscosity (McDonald et al., 2001) and the lower the $\mathrm{pH}$ of the digesta (Awati et al., 2006), due to the fermentative potential of the fiber. The soluble fiber content of citrus pulp is high $(31 \%)$, which can justify the increase in viscosity of the digesta in the stomach and cecum at both 35 and 50 days of age, respectively. Pluske et al. (2003) utilized sources of resistant starch and of soluble fiber in diets for weaned piglets and verified that the animals that received the two sources had an increase in the viscosity of the ileum content. Moreover, Högberg and Lindberg (2004) tested diets with low or high concentrations of insoluble fiber and observed that those with high concentrations reduced $\mathrm{pH}$ levels in the stomach and colon of weaned piglets.

Evaluating the interaction between treatments for the occurrence of $E$. coli in the small intestine at different slaughter ages, greater occurrences $(p<0.01)$ of this bacterium were observed at 35 days of age in the

Table 6 - pH and viscosity of the contents of the stomach, small intestine, and cecum, Escherichia coli. and Lactobacilus ssp. in the small intestine and in the cecum, and short chain fatty acids of the ileum-cecum content of piglets according to the sources of fiber and slaughter age - Assay 2.

\begin{tabular}{|c|c|c|c|c|c|c|c|c|c|c|}
\hline \multirow{2}{*}{ Variables } & \multicolumn{4}{|c|}{ Diets $(D)^{1}$} & \multicolumn{2}{|c|}{ Age (A) } & \multirow{2}{*}{$\begin{array}{l}\mathrm{CV}^{2} \\
(\%)\end{array}$} & \multicolumn{3}{|c|}{ Effects } \\
\hline & $C D$ & CEL & $\mathrm{SH}$ & $\mathrm{CP}$ & 35 & 50 & & D & $A$ & $\mathrm{D} \times \mathrm{A}$ \\
\hline \multicolumn{11}{|l|}{$\overline{\mathrm{pH}}$} \\
\hline Stomach & 3.35 & 3.15 & 3.59 & 3.28 & 3.19 & 3.49 & 21 & NS & NS & NS \\
\hline Small int. & 6.18 & 6.19 & 6.22 & 6.37 & 6.26 & 6.21 & 5 & NS & NS & NS \\
\hline Cecum & 6.04 & 6.09 & 5.70 & 5.61 & $6.13 \mathrm{a}$ & $5.58 \mathrm{~b}$ & 11 & NS & * & NS \\
\hline \multicolumn{11}{|c|}{ Viscosity $\left(\mathrm{mPa} \mathrm{s}^{-1}\right)$} \\
\hline Stomach & 1.78 & 1.89 & 2.28 & 2.16 & 2.73 & 1.32 & 17 & $*$ & ** & $*$ \\
\hline Small int. & 2.07 & 2.04 & 2.22 & 2.15 & $3.15 \mathrm{a}$ & $1.09 \mathrm{~b}$ & 10 & NS & ** & NS \\
\hline Cecum & 1.31 & 1.79 & 1.17 & 2.08 & 2.11 & 1.07 & 13 & $\star \star *$ & ** & ** \\
\hline \multicolumn{11}{|c|}{ E. coli. (log cfu g $\left.{ }^{-1}\right)$} \\
\hline Small int. & 6.95 & 6.93 & 6.55 & 6.37 & 7.37 & 6.04 & 9 & NS & ** & $*$ \\
\hline Cecum & $7.63 \mathrm{a}$ & $7.65 \mathrm{a}$ & $7.48 \mathrm{ab}$ & $6.66 b$ & 7.46 & 7.25 & 9 & * & NS & NS \\
\hline \multicolumn{11}{|c|}{ Lactobacilus (log cfu g ${ }^{-1}$ ) } \\
\hline Small int. & 7.40 & 7.53 & 7.83 & 7.49 & 7.50 & 7.63 & 12 & NS & NS & NS \\
\hline Cecum & 8.58 & 8.17 & 8.71 & 8.07 & 8.21 & 8.55 & 8 & NS & NS & NS \\
\hline \multicolumn{11}{|c|}{ Short chain fatty acids (mMol L-1) } \\
\hline Acetic & $30.11 b$ & $34.04 \mathrm{ab}$ & $34.17 a b$ & $40.64 \mathrm{a}$ & 33.95 & 35.53 & 18 & * & NS & NS \\
\hline Propionic & 11.63 & 13.49 & 13.97 & 12.31 & 13.16 & 12.55 & 25 & NS & NS & NS \\
\hline Butyric & 6.18 & 6.10 & 7.53 & 7.04 & 5.85 & 7.58 & 25 & NS & NS & NS \\
\hline
\end{tabular}

${ }^{1} \mathrm{CD}=$ control diet; $\mathrm{CEL}=$ diet containing $1.5 \%$ purified cellulose; $\mathrm{SH}=$ diet containing $3 \%$ soybean hulls and $\mathrm{CP}=$ diet containing $9 \%$ citrus pulp; ${ }^{2} \mathrm{Coefficient}$ of variation. Averages followed by the same letter in the row do not differ (Tukey, $p>0.05)$; NS = not significant $(p>0.05) ;{ }^{*}(p<0.05) ;{ }^{* *}(p<0.01)$. 
piglets receiving the control diet and the diet containing purified cellulose in relation to the piglets fed with the diet containing soybean hulls as the main source of fiber. The lower occurrence of $E$. coli in the small intestine of piglets fed diets containing soybean hulls and citrus pulp can be related to the higher quantity of soluble fiber present in these two ingredients, which increase fermentation and consequently, the production of short chain fatty acids, which inhibit the growth of this bacterium (Mateos et al., 2006). Similarly, Schiavon et al. (2004) verified a reduction in the quantity of $E$. coli in the feces of piglets fed with $12 \%$ beet pulp in the diet. At 50 days of age, the different sources of fiber did not influence the occurrence of this bacterium. Comparing slaughter age, the animals fed control diet and purified cellulose and slaughtered at 35 days of age had the highest $p<$ 0.01 ) occurrences of this bacterium when compared to the piglets that were slaughtered at 50 days of age.

Table 7 - Unfolding of the interaction among the sources of fiber in the diets and slaughter age on viscosity of the contents of stomach and cecum and quantities of Escherichia coli in the small intestine of piglets - Assay 2 .

\begin{tabular}{|c|c|c|c|c|c|}
\hline \multirow{2}{*}{ Variables } & \multirow{2}{*}{ Ages } & \multicolumn{4}{|c|}{ Experimental diets $^{1}$} \\
\hline & & $C D$ & CEL & $\mathrm{SH}$ & $\mathrm{CP}$ \\
\hline \multicolumn{6}{|c|}{ Viscosity (mPa s-1) } \\
\hline \multirow{2}{*}{ Stomach } & 35 & $2.61 \mathrm{a}$ & $2.74 \mathrm{a}$ & $3.06 \mathrm{a}$ & $2.54 \mathrm{a}$ \\
\hline & 50 & $0.96 \mathrm{bB}$ & $1.05 \mathrm{bB}$ & $1.50 \mathrm{bAB}$ & $1.79 \mathrm{aAb}$ \\
\hline \multirow{2}{*}{ Cecum } & 35 & $1.59 \mathrm{aB}$ & $2.54 \mathrm{aA}$ & $1.38 \mathrm{aB}$ & $2.93 \mathrm{aA}$ \\
\hline & 50 & $1.03 \mathrm{~b}$ & $1.04 \mathrm{~b}$ & $0.97 \mathrm{a}$ & $1.23 \mathrm{~b}$ \\
\hline \multicolumn{6}{|c|}{ E.coli. (log cfu g-1) } \\
\hline \multirow{2}{*}{ Small int. } & 35 & $8.05 \mathrm{Aa}$ & $7.94 \mathrm{Aa}$ & $6.53 \mathrm{aB}$ & $6.94 \mathrm{aB}$ \\
\hline & 50 & $5.86 \mathrm{~b}$ & $5.92 \mathrm{~b}$ & $6.57 \mathrm{a}$ & $5.81 \mathrm{a}$ \\
\hline
\end{tabular}

${ }^{1} \mathrm{CD}=$ control diet; $\mathrm{CEL}=$ diet containing $1.5 \%$ purified cellulose; $\mathrm{SH}=$ diet containing $3 \%$ soybean hulls and $\mathrm{CP}=$ diet containing $9 \%$ citrus pulp. Averages followed by same letters, upper case in the row and lower case in the column do not differ (Tukey, $p>0.05$ ).
Since we observed an increase in the concentration of acetic acid in the ileum-cecum content of the piglets fed diet containing citrus pulp when compared to piglets receiving the control diet, this result may have a direct relation to the reduction in the occurrence of $E$. coli because acetic acid can inhibit the growth of this bacterium (Roe et al., 2002). The concentrations of propionic $(p>0.05)$ and butyric $(p>0.05)$ acids were not influenced by the sources of fiber nor by slaughter age (Table 5). However, the addition of citrus pulp in the diet increased the concentration of acetic acid $(p<0.05)$ in the ileum-cecum content of the piglets when compared to those consuming the control diet.

The increase in concentration of acetic acid is probably due to the greater quantities of soluble fiber, as pectin, contained in this ingredient, which is highly fermentable, and acetate being the main product of pectin fermentation (Carneiro et al., 2008). Awati et al. (2006) evaluated two diets for weaned piglets, one semi-purified, poor in soluble fiber, and another containing beet pulp as a source of soluble fiber, and they verified that the addition of the source of soluble fiber increased the concentrations of acetic acid, propionic acid, and total fatty acids in the contents of the small intestine, cecum, and colon. Awati et al. (2006) observed that the addition of sources of fiber influenced the final products of fermentation in the large intestine of piglets, and that the type of fiber directly affected the fatty acid profile. However, for this profile to be altered, the quantity of substrate should be sufficient to modify or increase the intestinal microbiota (Knudsen, 2001; Schavion et al., 2004).

In relation to intestinal morphology (Table 8), the sources of fiber affected $(p<0.01)$ only the number of goblet cells in the duodenum, and that the piglets fed the diet containing soybean hulls presented higher values when compared to the piglets receiving the control diet and the diet including purified cellulose. This last diet resulted in the lowest $(p<0.01)$ values of goblet cells. The

Table 8 - Villi height, crypt depth, villi height and crypt depth ratio number of goblet cells and villi density in the duodenum and jejunum of piglets according to the sources of fiber and slaughter ages.

\begin{tabular}{|c|c|c|c|c|c|c|c|c|c|c|}
\hline & \multicolumn{4}{|c|}{ Experimental $\operatorname{diets}^{1}(\mathrm{D})$} & \multicolumn{2}{|c|}{ Ages (A) } & \multirow{2}{*}{$\begin{array}{l}\mathrm{CV}^{2} \\
(\%)\end{array}$} & \multicolumn{3}{|c|}{ Effects } \\
\hline & $C D$ & CEL & $\mathrm{SH}$ & $\mathrm{CP}$ & 35 & 50 & & $\mathrm{D}$ & $\mathrm{A}$ & $\mathrm{D} \times \mathrm{A}$ \\
\hline \multicolumn{11}{|c|}{ Duodenum } \\
\hline $\mathrm{VH}, \mu \mathrm{m}$ & 293.76 & 266.90 & 308.96 & 299.74 & $278.07 \mathrm{~b}$ & $306.61 \mathrm{a}$ & 12 & NS & * & NS \\
\hline $\mathrm{CD}, \mu \mathrm{m}$ & 176.22 & 163.91 & 185.84 & 166.12 & 177.84 & 168.21 & 13 & NS & NS & NS \\
\hline $\mathrm{VH} / \mathrm{CD}$ & 1.67 & 1.63 & 1.69 & 1.80 & $1.57 \mathrm{~b}$ & $1.82 \mathrm{a}$ & 7 & NS & ** & NS \\
\hline GC & $16.92 b$ & $14.10 \mathrm{c}$ & 19.79 a & $18.40 a b$ & 16.80 & 17.81 & 10 & $* *$ & NS & NS \\
\hline $\mathrm{VD}, \mathrm{cm}^{2}$ & 6985 & 7055 & 6607 & 7298 & 7231 & 6742 & 15 & NS & NS & NS \\
\hline \multicolumn{11}{|l|}{ Jejunum } \\
\hline $\mathrm{VH}, \mu \mathrm{m}$ & 328.24 & 275.45 & 262.74 & 275.26 & $254.02 b$ & $316.83 a$ & 16 & NS & ** & NS \\
\hline $\mathrm{CD}, \mu \mathrm{m}$ & 182.62 & 155.99 & 153.42 & 153.32 & 163.54 & 159.13 & 14 & NS & NS & NS \\
\hline $\mathrm{VH} / \mathrm{CD}$ & 1.78 & 1.77 & 1.74 & 1.81 & $1.55 \mathrm{~b}$ & $1.99 \mathrm{a}$ & 9 & NS & ** & NS \\
\hline GC & 8.97 & 7.68 & 9.58 & 10.13 & 7.62 & 10.57 & 14 & ** & ** & ** \\
\hline VD, $\mathrm{cm}^{2}$ & 7692 & 8786 & 7418 & 7449 & 8413 & 7260 & 12 & ${ }^{*}$ & ** & ${ }^{* *}$ \\
\hline
\end{tabular}

${ }^{1} \mathrm{CD}=$ control diet; $\mathrm{CEL}=$ diet containing $1.5 \%$ purified cellulose; $\mathrm{SH}=$ diet containing $3 \%$ soybean hulls and $\mathrm{CP}=$ diet containing $9 \%$ citrus pulp; ${ }^{2} \mathrm{Coefficients}$ of Variation; $\mathrm{VH}=$ villi height; $\mathrm{CD}=$ crypt depth; $\mathrm{VH} / \mathrm{CD}=$ villi height and crypt depth ratio; $\mathrm{GC}=$ number of goblet cells; VD = villi density. Averages followed by the same letter in the row do not differ (Tukey test, $p>0.05)$; NS = not significant $(p>0.05) ;{ }^{*}(p<0.05)$; ${ }^{* *}(p<0.01)$. 
slaughter ages influenced the villi height $(p<0.05)$ and the $\mathrm{VH} / \mathrm{CD}$ ratios $(p<0.01)$ in the duodenum. The animals slaughtered at 50 days of age had higher values for the two variables. In the jejunum, the sources of fiber in the diets did not affect the VH, CD and VH/CD variables ( $p>0.05)$. For this segment of the intestine, slaughter age influenced the $\mathrm{VH}(p<0.01)$ and the $\mathrm{VH} / \mathrm{CD}$ ratio $(p<0.01)$.

Interaction between the factors was verified for goblet cell $(p<0.01)$ count and villi density $(p<0.01)$ (Table 9). At 35 days of age, the animals fed control diets and diets with the inclusion of purified cellulose had lower numbers of goblet cells $(p<0.01)$ when compared to animals receiving the diets containing soybean hulls and citrus pulp. Nevertheless, at 50 days of age, no difference $(p>0.05)$ was found between the sources of fiber in the diets. In relation to slaughter ages, piglets slaughtered at 50 days of age had higher numbers of gob-

Table 9 - Unfolding of the interactions among sources of fiber in the diets and the slaughter ages for number of goblet cells and villi density in the jejunum of piglets.

\begin{tabular}{lccccc}
\hline \multirow{2}{*}{ Variables } & \multirow{2}{*}{ Ages } & \multicolumn{5}{c}{ Experimental diets ${ }^{1}$} \\
\cline { 2 - 6 } & & $\mathrm{CD}$ & $\mathrm{CEL}$ & $\mathrm{SH}$ & $\mathrm{CP}$ \\
\hline \multirow{2}{*}{$\mathrm{GC}$} & 35 & $6.20 \mathrm{bB}$ & $5.30 \mathrm{bB}$ & $9.56 \mathrm{aA}$ & $9.41 \mathrm{aA}$ \\
& 50 & $11.75 \mathrm{a}$ & $10.07 \mathrm{a}$ & $9.60 \mathrm{a}$ & $10.86 \mathrm{a}$ \\
\hline \multirow{2}{*}{$\mathrm{VD}, \mathrm{cm}^{2}$} & 35 & $9945 \mathrm{aA}$ & $9388 \mathrm{aA}$ & $7395 \mathrm{aB}$ & $6923 \mathrm{aB}$ \\
& 50 & $5440 \mathrm{bB}$ & $8183 \mathrm{aA}$ & $7441 \mathrm{aA}$ & $7974 \mathrm{aA}$ \\
\hline
\end{tabular}

${ }^{1} \mathrm{CD}=$ control diet; $\mathrm{CEL}=$ diet containing $1.5 \%$ purified cellulose; $\mathrm{SH}=$ diet containing $3 \%$ soybean hulls and $\mathrm{CP}=$ diet containing $9 \%$ citrus pulp; $\mathrm{GC}=$ number of goblet cells; $\mathrm{VD}=$ villi density. Averages followed by same letters, upper case in the row and lower case in the column do not differ (Tukey, $p>0.05$ ) let cells $(p<0.05)$ when they consumed the control diets and the diets containing purified cellulose.

The villus density in the jejunums of the piglets slaughtered at 35 days of age were higher $(p<0.01)$ in those that consumed the control diet and the diet containing purified cellulose when compared to the densities in the piglets receiving diets with soybean hulls and citrus pulp (Figure 1). For the animals slaughtered at 50 days of age, those fed diets containing sources of fiber presented higher $(p<0.01)$ villus density in relation to the animals in the control diet group (Figure 2). As for the effect of slaughter age, the piglets consuming the control diet had higher $(p<0.01)$ villus density at 35 days than at 50 days of age.

Although Jin et al. (1994) stated that the use of fibrous ingredients in the diet reduced the villi height and increased crypt depth, thus altering the VH/CD ratio, the addition of sources of fiber in diets were not sufficient to cause shortening of villi and deepening of crypts. The inclusion of sources of fiber can bring benefits to intestinal morphology due to a reduction in enteric problems (Hanczakoswska et al., 2008). Regarding the age of the animals, the villi height and the VH/CD ratios in the duodenum were greater at 50 days of age. This can be due to the decrease in villus height in the days following weaning, which is a natural response to the stress that the piglets face at this stage when submitted to changes in diet, loss of their mother's milk, and as a consequence, a reduction in feed intake. However, after this period of adaptation, they recuperate and villi height increases, which also increases the VH/CD ratio (Cera et al., 1988).
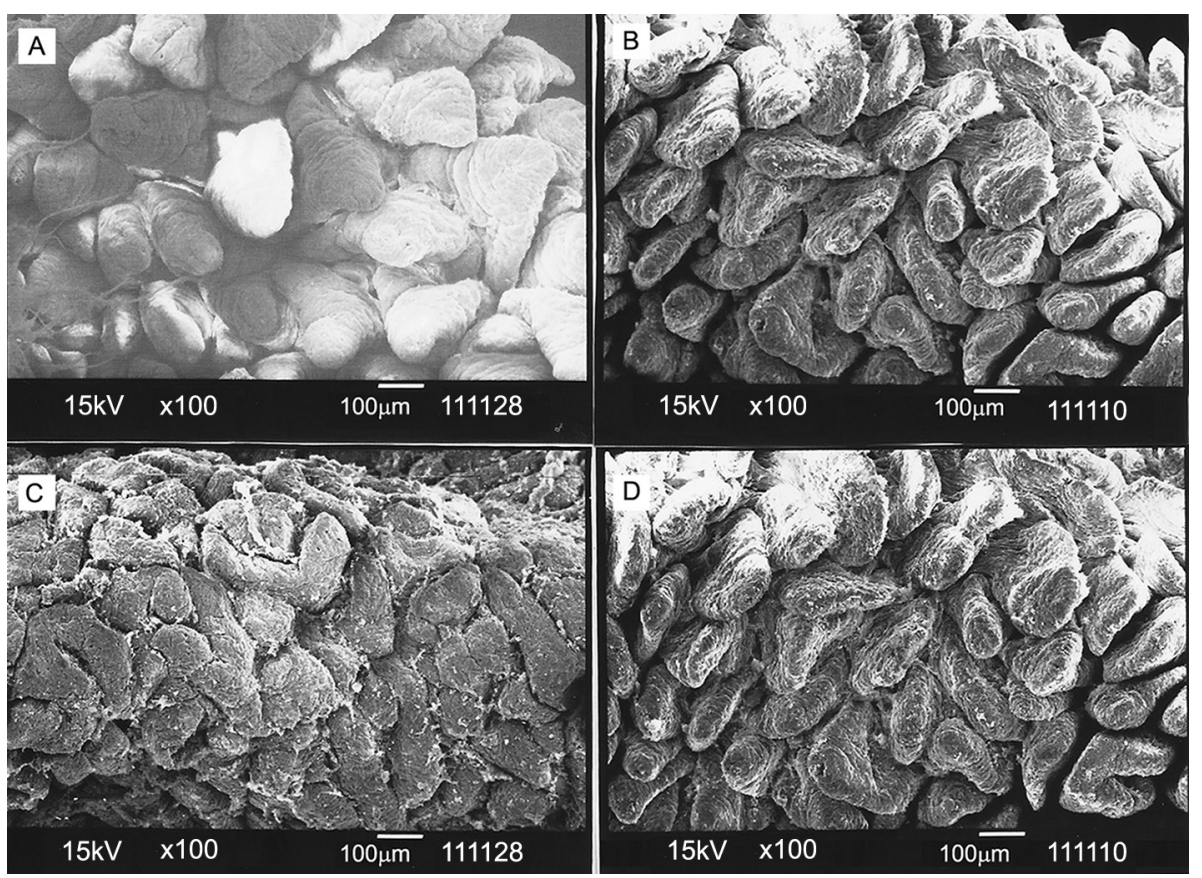

Figure 1 - Electron micrographs of jejunum from piglets at 35 days of age, according to dietary treatments: Control (A), Purified cellulose (B), Soybean hulls (C) e Citrus pulp (D). $A=150 X$. 
The reduction in the number of goblet cells of the duodenum (Figures 3 and 4) of the animals fed a diet containing purified cellulose may have been caused by changes that occur in the mucosa by the presence of the fibrous fraction, since these cells cause production of mucin for the protection of the epithelium (Brown et al., 1988). Thus, the presence of dietary fiber modifies the quantity of secreted mucin, and when the level of
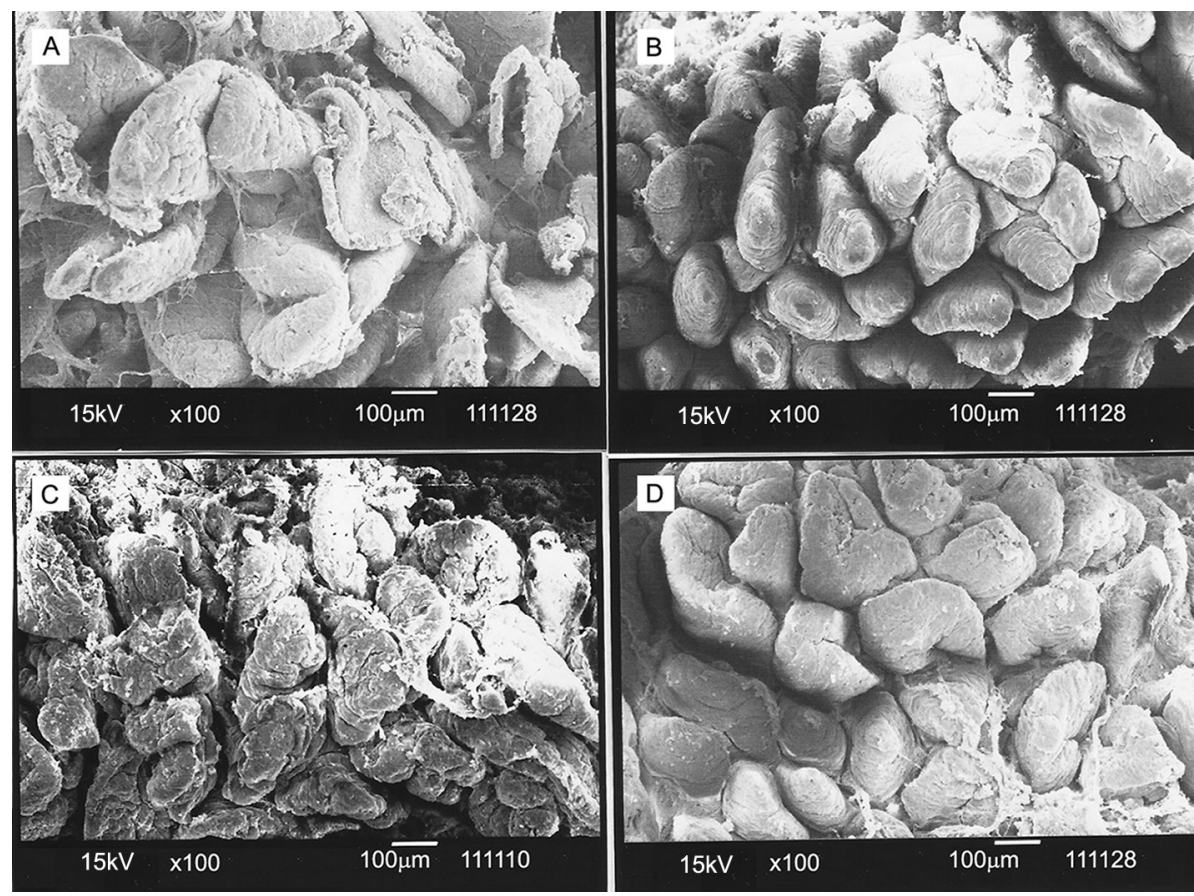

Figure 2 - Electron micrographs of jejunum from piglets at 50 days of age, according to dietary treatments: Control (A), Purified cellulose (B), Soybean hulls (C) e Citrus pulp (D). $A=150 X$.
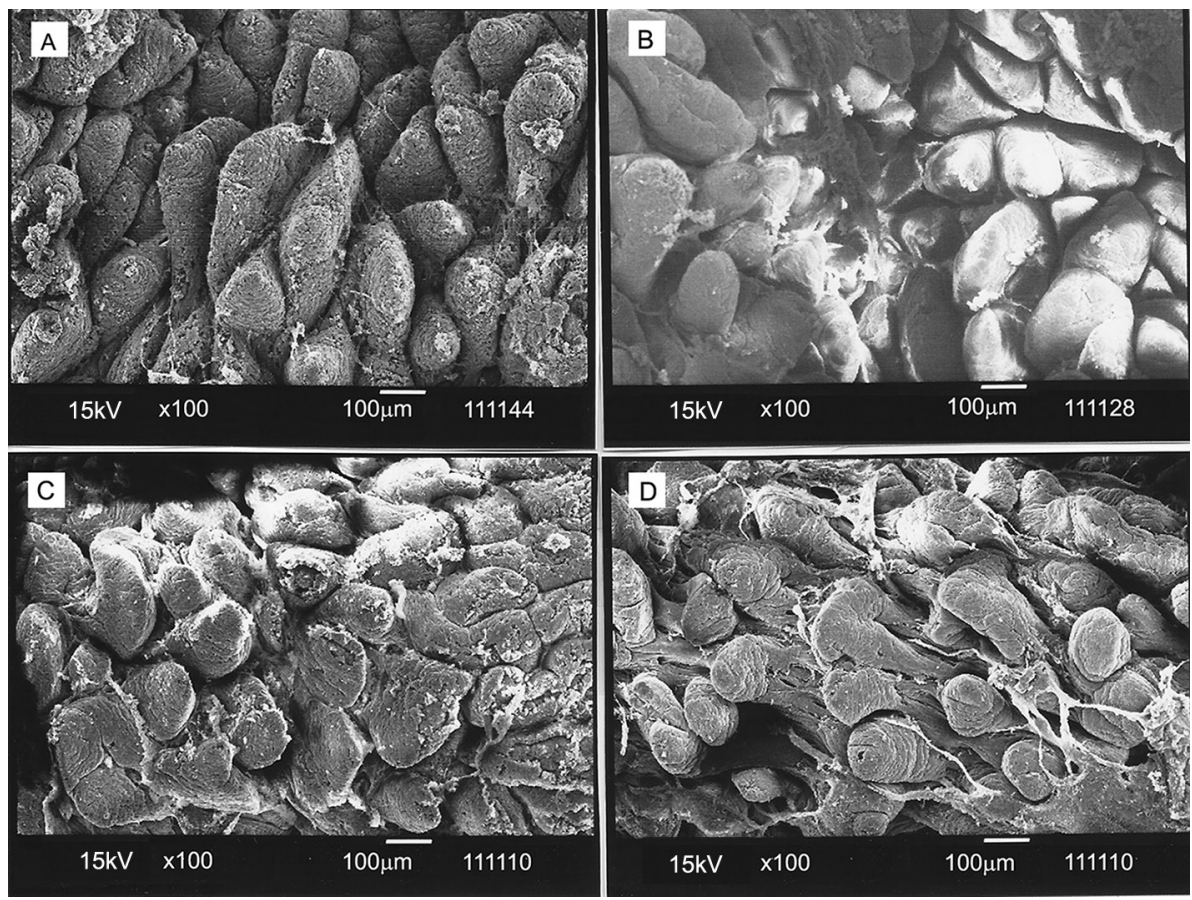

Figure 3 - Electron micrographs of duodenum from piglets at 35 days of age, according to dietary treatments: Control (A), Purified cellulose (B), Soybean hulls (C) e Citrus pulp (D). $A=150 X$. 

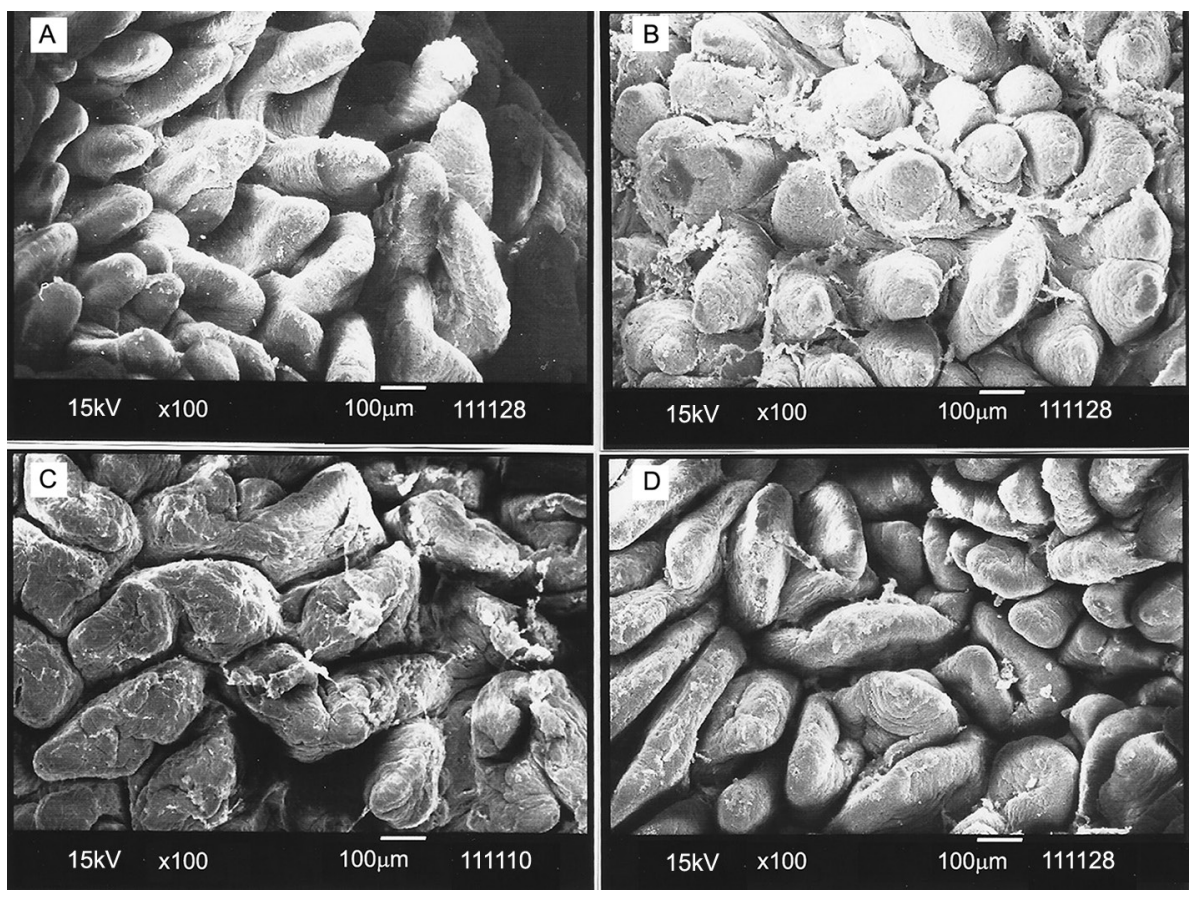

Figure 4 - Electron micrographs of duodenum from piglets at 50 days of age, according to dietary treatments: Control (A), Purified cellulose (B), Soybean hulls (C) e Citrus pulp (D). A=150X.

pectin in the diet is high, there is a reduction in the secretion of this substance, which consequently increases the number of goblet cells (More et al., 1987). This effect was observed in our study, when the diets containing sources of soluble fiber, such as citrus pulp and soybean hulls, showed higher levels of this variable as compared to the diet containing purified cellulose. In the jejunum, the number of goblet cells was influenced by the diet and the age of the animals. At 35 days, those which had consumed control diets and diets with inclusion of purified cellulose had lower values when compared to the animals receiving diets containing soybean hulls and citrus pulp. This can be explained because fibrous diets can actuate on intestinal mucosa, and stimulate the production and liberation of mucin by intestinal glands (Morel et al., 2003), as stated previously.

Villi density in the jejunum was affected by diets and slaughter ages of the animals. At 50 days, the piglets fed diets containing sources of fiber had higher densities than the piglets fed control diet. These results differed from those of other authors, who observed that inclusions of sources of fiber in the diet reduced villi density by increased shedding of the intestinal mucosa (Hedemann et al., 2006; Sehm et al., 2006). The absence of this deleterious effect on intestinal mucosa may have occurred due to the increase of goblet cells, mainly for the animals fed with diets containing citrus pulp and soybean hulls, which may have influenced the production of mucin, and consequently increase the protection of the intestinal epithelium.
In conclusion, the fiber sources do not promote a decrease in nutrient digestibility and metabolizable energy of diets up to the studied levels. Among the fiber sources, purified cellulose in piglet diets promote better performance of animals, due to the modulation of the small intestine microbiota, with lower $E$. coli occurrence resulting in higher villus density.

\section{References}

Association of Official Analytical Chemists [AOAC]. 2005. Official Methods of Analysis. 18ed. AOAC, Gaithersburg, MD, USA.

Awati, A.; Williams, B.A.; Bosch, M.W.; Gerrits, W.J.; Verstegen, M.V. 2006. Effect of inclusion of fermentable carbohydrates in the diet on fermentation end-product profile in feces of weanling piglets. Journal of Animal Science 84: 2133-2140.

Bikker, P.; Dirkzwager, A.; Fledderus, J.; Trevisi, P.; Huërou-Luron, I.; Lallès, J.P.; Awati, A. 2006. The effect of dietary protein and fermentable carbohydrates levels on growth performance and intestinal characteristics in newly weaned piglets. Journal of Animal Science 84: 3337-3345.

Brown, P.J.; Miller, B.G.; Stokes, C.R. 1988. Histochemistry of mucins of pig intestinal secretory epithelial cells before and after weaning. Journal of Comparative Pathology 98: 313323.

Carneiro, M.S.C.; Lordelo, M.M.; Cunha, L.F.; Freire, J.P.B. 2008. Effects of dietary fibre source and enzyme supplementation on faecal apparent digestibility, short chain fatty acid production and activity of bacterial enzymes in the gut of piglets. Animal Feed Science and Technology 146: 124-136. 
Cera, K.R.; Mahan, D.C.; Cross, R.F. 1988. Effect of age, weaning and post weaning diet on small intestinal growth and jejunal morphology in young swine. Journal of Animal Science 66: 574-584.

Drochner, W.; Kerler, A.; Zacharias, B. 2004. Pectin in pig nutrition, a comparative review. Journal Animal Physiology and Animal Nutrition 88: 367-380.

Erwin, E.S.; Marco, G.J.; Emery, E.M. 1961. Volatile fatty acid analyses of blood and rumen fluid by gas chromatography. Journal of Dairy Science 44: 1768-1771.

Freire, J.P.B.; Guerreiro, A.J.G.; Cunha, L.F.; Aumaitre, A. 2000. Effect of dietary fiber source on total tract digestibility, caecum volatile fatty acids and digestive transit time in the weaned piglet. Animal Feed Science and Technology 8: 71-83.

Han, Y.K.; Han, K.Y.; Lee, J.H. 2005. Effects of insoluble dietary fiber supplementation on the performance and digestibility of wealing pigs. Journal of Animal Science and Technology 47: 565-572.

Hanczakowska, E.; Swiatkiewicz, M.; Bialecka, A. 2008. Pure cellulose as feed supplement for piglets. Medycyna Wet 64: 45-48.

Hedemann, M.S.; Eskildsen, M.; Laerke, H.N.; Pedersen, C.; Lindberg, J.E.; Laurine, P.; Kdnudsen, K.E. 2006. Intestinal morphology and enzymatic activity in newly weaned pigs fed contrasting fiber concentrations and fiber properties. Journal of Animal Science 84: 1375-1386.

Hendrix, D.L. 1993. Rapid extraction and analysis of nonstructural carbohydrates in plant tissues. Crop Science 33: 1306-1311.

Hopwood, D.E.; Pethick, D.W.; Hampson, D.J. 2002. Increasing the viscosity of the intestinal contents stimulates proliferation of enterotoxigenic Escherichia coli and Brachispyra pilosicoli in weaned pigs. British Journal of Nutrition 88: 523-532.

Högberg, A.; Lindberg, J.E. 2004. Influence of cereal non-starch polysaccharides and enzyme supplementation on digestion site and gut environment in weaned piglets. Animal Feed Science and Technology 116: 113-128.

Jin, L.; Reynolds, L.P.; Redmer, D.A.; Crenshaw, J.D. 1994. Effects of dietary fiber on intestinal growth, cell proliferation, and morphology in growing pigs. Journal of Animal Science 72: 2270-2278.

Knudsen, K.E.B. 2001. The nutritional significance of "dietary fibre" analysis. Animal Feed Science and Technology 90: 3-20.

Krieg, N.R.; Holt, J.C. 1994. Bergey's Manual of Systematic Bacteriology. 9ed. Willians and Wilkins, Baltimore, MD, USA.

Lennette, J.K.; Spauding, L.H.; Truant, J.P. 1985. Manual of Clinical Microbiology. American Society for Microbiology, Washignton, DC, USA.

Mateos, G.G.; Martin, F.; Latorre, M.A.; Vicente, B.; Lazaro, R. 2006. Inclusion of oat hulls in diets for young pigs based on cooked maize or cooked rice. Animal Science 82: 57-63.

Matterson, L.D.; Potter, L.M.; Stutz, N.W.; Singsen, E.P. 1965 The metabolizable energy of feed ingredients for chicken. Research Report 7: 3-11.

McDonald, D.E.; Pethick, D.W.; Mullan, B.P.; Hampson, D.J. 2001. Increasing viscosity of the intestinal contents alters small intestinal structure and intestinal growth, and stimulates proliferation of enterotoxigenic Escherichia coli in newlyweaned pigs. British Journal of Nutrition 86: 487-498.
Molist, F.; Gomes-De-Segura, A.; Gasa, A.; Manzanilla, E.G.; Anguita, M.; Perez, J.F. 2009. Effects of the insoluble and soluble dietary fibre on the physicochemical properties of digesta and microbial activity in early weaned piglets. Animal Feed Science and Technology 149: 346-353.

Montagne, L.; Pluske, J.R.; Hampson, D.J. 2003. A review of interactions between dietary fibre and the intestinal mucosa, and their consequences on digestive health in young nonruminant animals. Animal Feed Science and Technology 108: 95-117.

More, J.; Fioramonti, J.; Benazet, F. 1987. Histochemical characterization of glycoproteins present in jejunal and colonic globet cells of pigs on different diets. Histochemistry 87: 189194.

Morel, P.C.H.; Padilla, R.M.; Ravindran, G. 2003. Effect of nonstarch polysaccharides on mucin secretion and endogenous amino acid losses in pigs. Asian-Australian Journal of Animal Science 9: 1332-1338.

Miller, G.L. 1959. Use of dinitrosalicylic acid reagent for determination of reducing sugar. Analytical Chemistry 31: 426428.

Pluske, J.R.; Black, B.; Pethick, D.W.; Mulla, B.P.; Hampson, D.J. 2003. Effects of different sources and levels of dietary fibre in diets on performance, digesta characteristics and antibiotic treatment of pigs after weaning. Animal Feed Science and Technology 107: 129-142.

Roe, A.J.; O`Byrne, C.; McLaggan, D.; Booth, I.R. 2002. Inhibition of Escherichia coli growth by acetic acid: a problem with methionine biosynthesis and homocysteine toxicity. Microbiology 148: 2215-2222.

Rostagno, H.S.; Albino, L.F.T.; Donzele, J.L.; Gomes, P.C.; Oliveira, R.F.; Lopes, D.C.; Ferreira, A.S.; Barreto, S.L.T. 2005. Brazilian Tables for Poultry and Swine: Composition of Feedstuffs and Nutritional Requirements $=$ Tabelas Brasileiras para Aves e Suínos: Composição dos Alimentos e Exigências Nutricionais. UFV, Viçosa, MG, Brazil. (in Portuguese)

Schiavon, S.; Tagliapietra, F.; Bailoni, I.; Bortolozzo, A. 2004. Effects of sugar beet pulp on growth and health status of weaned piglets. Italian Journal of Animal Science 3: 337-351.

Sehm, J.; Limdermayer, H.; Dummer, C.; Treutter, D.; Pfafl, M.W. 2006. The influence of polyphenol rich apple pomace or red wine pomace diet on the gut morphology in weaning piglets. Journal of Animal Physiology and Animal Nutrition 91: 289-296.

Tolosa, E.M.C.; Rodrigues, C.J.; Behmer, A.O.; Freitas Neto, A.G. 2003. Manual techniques to normal histology and pathology = Manual de técnicas para histologia normal e patológica. 2ed. Manole, São Paulo, SP, Brazil. (in Portuguese).

Watanabe, P.H.; Thomaz, M.C.; Ruiz, U.S.; Santos, V.M.; Fraga, A.L.; Pascoal, L.A.F.; Silva, S.Z.; Farias, H.G. 2010. Effect of inclusion of citrus pulp in diet of finishing swines. Brazilian Archives of Biology and Technology 53: 705-718.

Wenk, C. 2001. The role of dietary fibre in the digestive physiology of the pig. Animal Feed Science and Technology 90: 21-33.

Whitney, M.H.; Shurson, G.C.; Guedes, R.C. 2006. Effects of dietary inclusion of distillers dried grains with soluble, soybean hulls, or a polyclonal antibody product on the ability of growing pigs to resist a Lawsonia intracellularis challenge. Journal of Animal Science 84: 1880-1889. 